\title{
Remotely Identification and Differentiation of Ficus Species in Alexandria City Using Spectral Reflectance Measurements
}

\author{
Nashwa H. Mohamed ${ }^{1}$, Nader A. El-Shanhorey ${ }^{2}$ and Salah E. Elsayed ${ }^{3}$
}

\begin{abstract}
This study was carried out in Alexandria city on eighteen Ficus species (Family Moraceae), to examine how far the remote sensing is considered as an applicable technique and as vegetation indices can differentiate between vegetation cover species depending on spectral reflectance characteristics for each tree species leaves. Results showed that absorption and reflectance spectral characteristics of leaves of each tree species were significantly differentiated by spectral signature curve and average of digital number (DN), that gives the highest value for species with large, thick and dark green leaves such as Ficus platyphylla, Ficus lyrata and Ficus altissima, comparing to species with small, white green colored leaves like Ficus microcarpa Hawai, which showed the lowest value. The same trend was shown by, Normalized difference Vegetation index (NDVI) and rationally, the chlorophyll content. On the other hand results of Simple ratio (SR) index were not significantly differed among studied species. It is noticeable of that reflectance of (nearinfrared (NIR) region) by leaves varied to its color, size, thickness and internal structure, so this electro-magnetic radiation (EMR) region can be used successfully for species classification. There were a highly correlation between chlorophyll content and NDVI and SR, while results showed no significant correlation between chlorophyll content and DN.
\end{abstract}

Key words: Ficus, remote sensing, vegetation indices, NDVI, SR index, spectral curve, chlorophyll.

\section{INTRODUCTION}

The genus Ficus, (Family Moraceae) is one of the largest and most diverse genera of woody plants (Berg and Wiebes, 1992), comprising approximately of 750 species distributed in tropical and subtropical zones. Most Ficus species are diploid with the basic chromosome number $\mathrm{x}=13$ (Condit, 1969). Among cultivated species, Ficus afzelii, F. altissima, F. aspera, $F$. benghalensis, $F$. benjamina, $F$. elastica decora, $F$. elastica golden, F. elastica varegata, F. lutea, F. lyrata, F. macrophylla, F. microcarpa Hawaii, F. microcarpa nitida, $F$. rubiginosa, $F$. petiolaris, $F$. platyphylla, $F$. pyriformis and $F$. sycomorus which are grown for their ornamental value either as landscape plants in the tropics and subtropics (Dehgan, 1998) or foliage plants used for interiorscaping (Chen, et al., 2005). In addition, Ficus spp. products are among the most important examples of natural ones, which have been widely used both as a food and as a medicine (Ghadam et al., 2011).

Ficus species have wide distribution and uses worldwide traditionally as medicine, vegetable, food, fodder, and fuel wood etc. Ficus often grown is an attractive ornamental tree found mostly outdoors and is frequently encountered along city streets lining parkways, medians and sidewalks. It is planted in parks and other large, open spaces but is, perhaps, most familiar as a street tree and some species of Ficus are commonly used as interior ornamentals. Under Egyptian conditions, Ficus trees have special importance in parks and in the newly established cities to reduce the harsh impact of the desert environment. But, from the point of view of architecture and urbanism, planting Ficus trees on metropolitan areas is absolutely inadequate, since it causes severe damage to city structures. Its roots are aggressive, superficial, thick, very strong, and grow up to a hundred meters long (Toscan et al., 2010), which enables them to fracture concrete (Starr et al., 2003), affecting foundations and walls on houses and buildings, as well as civil works like bridges and street posts, roads and streets. Also, in addition, roots from Ficus trees break and/or obstruct underground pipes from water and sewage systems (Alanís Flores, 2005; Martelli \& Barbosa, 2010; Vargas-Garzón and Molina-Prieto, 2010).

Remote sensing is an important source of qualitative and quantitative information for estimation of the vegetation cover activity and land use specially in large areas. Estimation of canopy biophysical variables are very important in different studies such as meteorology, agriculture and ecology (Susan et al., 2011).

It is known that the spectral properties of plant species are depended on plant physiology, morphology or anatomy (Kycko et al. 2014; Jarocinska et al. 2016). Such spectral profiles of leaves in regions from visibleinfrared (VNIR) to shortwave infrared (SWIR), are differ by dry matter contents, pigments, e.g.

\footnotetext{
${ }^{1}$ Timber Trees Research Department, Horticulture Research Institute, Agriculture Research Center, Alexandria, Egypt.

${ }^{2}$ Botanical Gardens Research Department, Horticultural Research Institute, Agriculture Research Center, Alexandria, Egypt.

${ }^{3}$ Evaluation of Natural Resources Department, Environmental Studies and Research Institute, Sadat City University, Egypt

Received остовR 23, 2018, Accepted November 21, 2018
} 
chlorophyll, carotenoid, and water content (JeanBaptiste et al, 2008). Variations in plant canopy and leaf structure, pigment and water content lead to change in vegetation reflectance properties, even between closely related species. So, species identification is possible from these unique spectral properties (Thenkabail et al., 2000). Where, absorption, transmission or reflection of the electromagnetic spectrum by plants can play a significant role in the monitoring of ecosystem changes.

Vegetation indices were designed to evaluate vegetation condition, land cover classification and phenology, climate and land use detection and drought monitoring (Padilla et al., 2011). Remote sensing method has several vegetation indices. Normalized difference Vegetation index (NDVI) is an important , common and widely used index in research on global environmental and climatic change (Bhandari and Kumar, 2012). NDVI is calculated as a ratio difference between measured canopy reflectance in the red and near infrared bands respectively (Nageswara et al., 2005).

Little is known about leaf optical properties of tropical trees and for identifying tropical tree species using remote sensing. So, Lee et al. (1990), have studied leaf optical properties of tropical sun and shade species, as well as Avalos et al. (1999), who worked on leaf optical properties of tropical dry forest trees and lianas. Cochrane, (2000) has estimated the reflectance of leaf or branch samples to differentiate species of tropical trees. Moreover, Clark et al. (2005) have made success to determine seven tropical tree species at the leaf, pixel, and crown levels. No doubt, that the species classification has several applications, such as monitoring endangered or commercial tree species, characterizing biodiversity, monitoring changes in species composition over time and changes in tree demography associated with global environmental changes.

Urban vegetation cover has a lot of tree species to be defined, monitored and surveyed. For instance, Ficus considered one of the most used trees in Egypt as an urban and garden tree. So, the aim of this study to examine how far the remote sensing can aid in classifying and defying the differences among tree species, especially these belong to the same genus not only for canopy level, but also at leaf level. So, we used some tree species belongs to Ficus genus to discriminate among them using leaf spectral reflectance.

\section{MATERIALS AND METHODS}

\section{1-Studied area and tree species:}

This study was carried out in August, 2016 in Alexandria city, Egypt, at Research Department , Antoniades Garden. Leaves samples of eighteen tree species belongs to Ficus genus, Family Moraceae were collected from a big and mature trees. Three species (Ficus aspera G. Forst., Ficus elastica var Golden and Ficus elastica var varigata) were collected from Faculty of agriculture garden, El shatby. While, leaves samples of the rest fifteen species were collected from mature trees planted in Antoniades garden Table (1) summarized studied species.

\section{Sampling}

Leaves sample of each tree species was collected from mature trees to be accurately representative for their species. One tree was selected from each species. A sample of four leaves was collected randomly from the crown of each tree, at the four crown direction one leave was selected from every orient. Samples of fully exposed to sunlight leaves from crown upper part were selected randomly, then were washed and prepared to spectral reflectance measurements.

\section{Equipments and measurements}

-Spectral reflectance was measured using the passive reflectance sensor (tec5, Oberursel, Germany). This passive sensor contains two units; one unit to detect the solar radiation as a reference signal, while the second unit measures the reflectance of leaves with an angle of view of $12^{\circ}$. Leaf spectral reflectance was taken from $0.25 \mathrm{~m}$ distance and field of view is $0.05 \mathrm{~m}^{2}$. The spectral range of the passive sensor is $302-1148 \mathrm{~nm}$, with a spectral bandwidth of $2 \mathrm{~nm}$ (figure1), (Elsayed et al., 2015).

-A hand-held chlorophyll meter for leaf chlorophyll content was used. 
Table 1.List and phonological properties of the studied Ficus species

\begin{tabular}{|c|c|c|c|c|c|c|c|c|c|c|c|c|}
\hline \multirow[b]{2}{*}{ No } & \multirow[b]{2}{*}{ Species } & \multirow{2}{*}{$\begin{array}{c}\text { Tree } \\
\text { height } \\
\text { average }(m)\end{array}$} & \multicolumn{6}{|c|}{ leaves } & \multicolumn{4}{|c|}{ Fruit } \\
\hline & & & Type & Shape & $\begin{array}{l}\text { Length } \\
(\mathrm{cm})\end{array}$ & Texture & color & veins & Type & Shape & $\begin{array}{l}\text { Diameter } \\
\quad(\mathrm{cm})\end{array}$ & color \\
\hline 1 & Ficus sycamores $\mathbf{L}$. & 20 & Simple & Elliptical & $8-12$ & Distichous & Dark Green & Eminent & Fig & Globose & $4.0-10.0$ & Orange- Red \\
\hline 2 & Ficus aspera G.Forst. & 6 & Simple & $\begin{array}{l}\text { Ovate- } \\
\text { Elliptic }\end{array}$ & $19-22$ & Distichous & $\begin{array}{l}\text { Green - } \\
\text { White }\end{array}$ & Eminent & Fig & Small & $2.0-3.0$ & Pink-Purple \\
\hline 3 & Ficus elastica var. Golden & 20 & Simple & Elliptical & $12-30$ & Coriaceous & $\begin{array}{l}\text { Green - } \\
\text { Yellow }\end{array}$ & Prominent & Fig & Small & $1.5-2.0$ & Green-Yellow \\
\hline 4 & Ficus petiolaris Kunth & 15 & Simple & Deltoid & $6-15$ & Coriaceous & $\begin{array}{l}\text { Green - } \\
\text { Yellow }\end{array}$ & Eminent & Fig & Globose & $3.0-5.0$ & Light green \\
\hline 5 & Ficus microcarpa Hawaii & 5 & Simple & $\begin{array}{l}\text { Ovate- } \\
\text { Elliptic }\end{array}$ & $4-7$ & Coriaceous & $\begin{array}{l}\text { Green - } \\
\text { White }\end{array}$ & Prominent & Fig & Small & $1.0-1.5$ & Orange- Red \\
\hline 6 & Ficus benghalensis $\mathbf{L}$. & 30 & Simple & Elliptical & $10-15$ & Coriaceous & Dark Green & Yellow & Fig & Globose & $2.0-3.0$ & Red \\
\hline 7 & Ficus platyphylla Delile & 25 & Simple & $\begin{array}{l}\text { Ovate - } \\
\text { elliptic }\end{array}$ & $30-45$ & Coriaceous & Glossy Green & Marbled & Fig & Globose & $4.0-6.0$ & Orange- Red \\
\hline 8 & Ficus lyrata Warb. & 12 & Simple & $\begin{array}{l}\text { Fiddle- } \\
\text { shaped }\end{array}$ & $30-45$ & Coriaceous & Glossy Green & Eminent & Fig & Globose & $2.0-4.0$ & Green - White \\
\hline 9 & $\begin{array}{l}\text { Ficus afzelii G.Don ex } \\
\text { Loud }\end{array}$ & 20 & Simple & Obovate & $30-45$ & Distichous & Dark Green & Eminent & Fig & Big & $1.5-2.5$ & Green \\
\hline 10 & $\begin{array}{l}\text { Ficus microcarpa nitida } \\
\text { L.f. }\end{array}$ & 20 & Simple & $\begin{array}{l}\text { Ovate- } \\
\text { Elliptic }\end{array}$ & $4-7$ & Coriaceous & Dark Green & Prominent & Fig & Small & $1.0-1.5$ & Pink-Purple \\
\hline 11 & $\begin{array}{l}\text { Ficus elastica var. } \\
\text { varigata }\end{array}$ & 20 & Simple & Elliptical & $12-30$ & Coriaceous & $\begin{array}{l}\text { Green - } \\
\text { White }\end{array}$ & Prominent & Fig & Small & $1.5-2.0$ & Green-Yellow \\
\hline 12 & Ficus benjamina $\mathbf{L}$. & 20 & Simple & $\begin{array}{l}\text { Ovate- } \\
\text { Elliptic }\end{array}$ & $4-6$ & Coriaceous & Dark Green & Prominent & Fig & Small & $1.0-2.0$ & Green-Yellow \\
\hline 13 & Ficus elastica var. decora & 60 & Simple & Elliptical & $12-30$ & Coriaceous & Glossy Green & Prominent & Fig & Small & $1.5-2.0$ & Green-Yellow \\
\hline 14 & $\begin{array}{l}\text { Ficus macrophylla Desf } \\
\text { ex Pers. }\end{array}$ & 45 & Simple & Elliptical & $15-30$ & Coriaceous & $\begin{array}{l}\text { Green -/ } \\
\text { Brassy }\end{array}$ & Prominent & Fig & Small & $2.0-2.5$ & $\begin{array}{l}\text { Purple - } \\
\text { Yellow }\end{array}$ \\
\hline 15 & Ficus altissima Blume & 30 & Simple & $\begin{array}{l}\text { Ovate- } \\
\text { Elliptic }\end{array}$ & $10-20$ & Coriaceous & Dark Green & Marbled & Fig & Globose & $2.0-2.5$ & Orange \\
\hline 16 & Ficus lutea Vahl & 25 & Simple & $\begin{array}{l}\text { Ovate- } \\
\text { Elliptic }\end{array}$ & $13-43$ & Coriaceous & Glossy Green & Yellow & Fig & Globose & $1.5-3.0$ & $\begin{array}{l}\text { Yellow } \\
\text { reddish }\end{array}$ \\
\hline 17 & Ficus rubiginosa Desf & 30 & Simple & Ovate & $4-20$ & Coriaceous & Glossy Green & Eminent & Fig & Small & $1.0-1.5$ & Yellow - Red \\
\hline 18 & $\begin{array}{l}\text { Ficus pyriformis } \\
\text { Hook.\&arn. }\end{array}$ & 20 & Simple & Lanceolate & $10-14$ & Coriaceous & Glossy Green & Prominent & Fig & Small & $1.0-1.5$ & Light green \\
\hline
\end{tabular}

Badr M.D. (2003). Encyclopedia trees and environment. Monshaat Al-Maarif - Alexandria, Egypt, pp.747-824.

Heneidy S.Z. (2010). Plant atlas the botanic garden - Faculty of Science, Alexandria University. Monshaat Al-Maarif - Alexandria, Egypt, pp.429-443. 


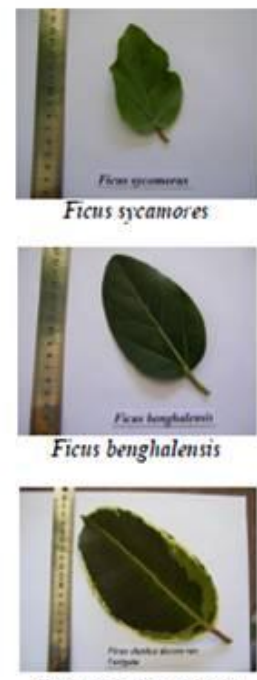

Ficus elastica varigata
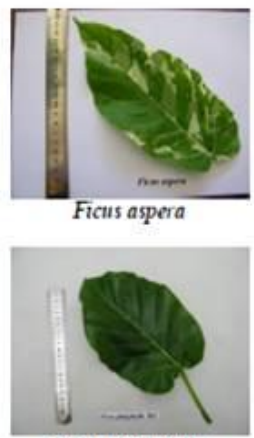

Ficus platyphiylla

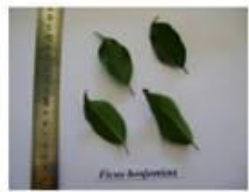

Ficus benjamina

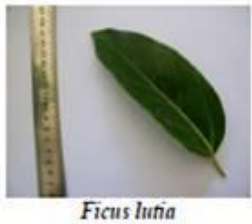

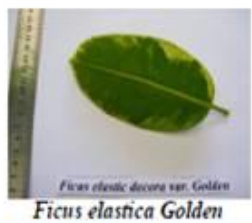

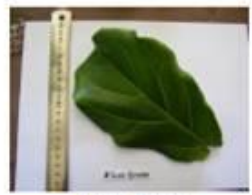

Ficus lyrata

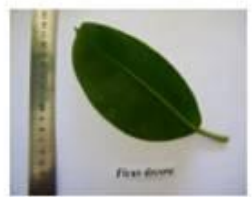

Ficus elastic decora

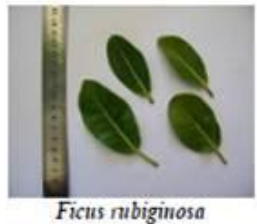

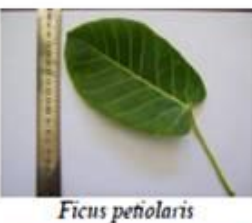

Ficus petiolaris

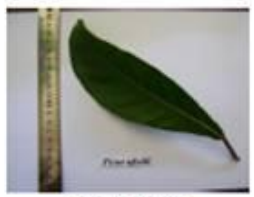

Ficus affelin

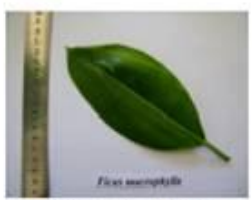

Ficus macroplylla

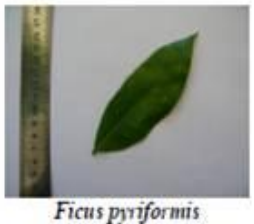

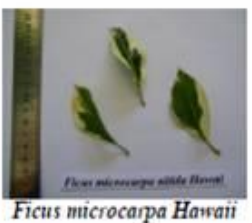

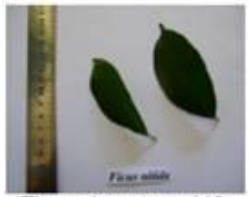

Ficus microcarpa nitida

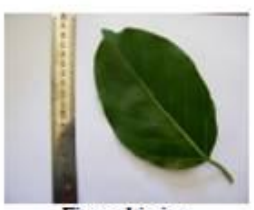

Ficus altissima

Figure 1. Eighteen Ficus species used to study the morphological diversity through using spectral reflectance measurements

\section{Measurements and calculations:}

\section{- Spectral reflectance curve.}

The digital numbers (DN) of each different tree species were extracted from $302-1148 \mathrm{~nm}$ wave length range, and plotted to show the leaves behavior of each tree species in different wavelengths of the spectrum.

\section{- Digital number (DN)}

The average of digital numbers (DN) of each different tree species was extracted from visible bands, and plotted to show the behavior of leaves of each tree species in different wavelengths of the spectrum.

Vegetation indices:

Normalized difference Vegetation index (NDVI)

$$
N D V I=(N I R-R) /(N I R+R)
$$

Where: NIR is Near-infrared wave band

$\mathrm{R}$ is red wave band

NDVI related to changes in amount of green biomass, pigment content and concentration and leaf water stress etc. (Tucker and Sellers, 1986; Fassnacht $e t$ al., 1997). Value of NDVI is ranges between -1 to 1 while, NDVI value close to 1 indicates very dense vegetation, while value near 0 indicates bare soil or very sparse vegetation.
Simple Ratio (SR)

$$
S R=N I R / R
$$

Near-infrared / Red reflectance ratio Related to changes in amount of green biomass, pigment content and concentration and leaf water stress etc. (Tucker, 1979 ;Baret and Guyot, 1991).

\section{- Total chlorophyll content}

-Total chlorophyll content was determined as a SPAD unites from the fresh leaves of plants for the different treatments under the experiment at the end of the season using Minolta (chlorophyll meter) SPAD 502 according to Yadava (1986).

\section{Statistical analysis}

The layout of the experiment was complete randomize design (CRD) with 4 replicates; Means were compared by L.S.D. test at 5\% level of probability according to (Snedecor and Cochran, 1989).

The correlation between leaves chlorophyll content and vegetation indices were calculated according to Federer (1955). 


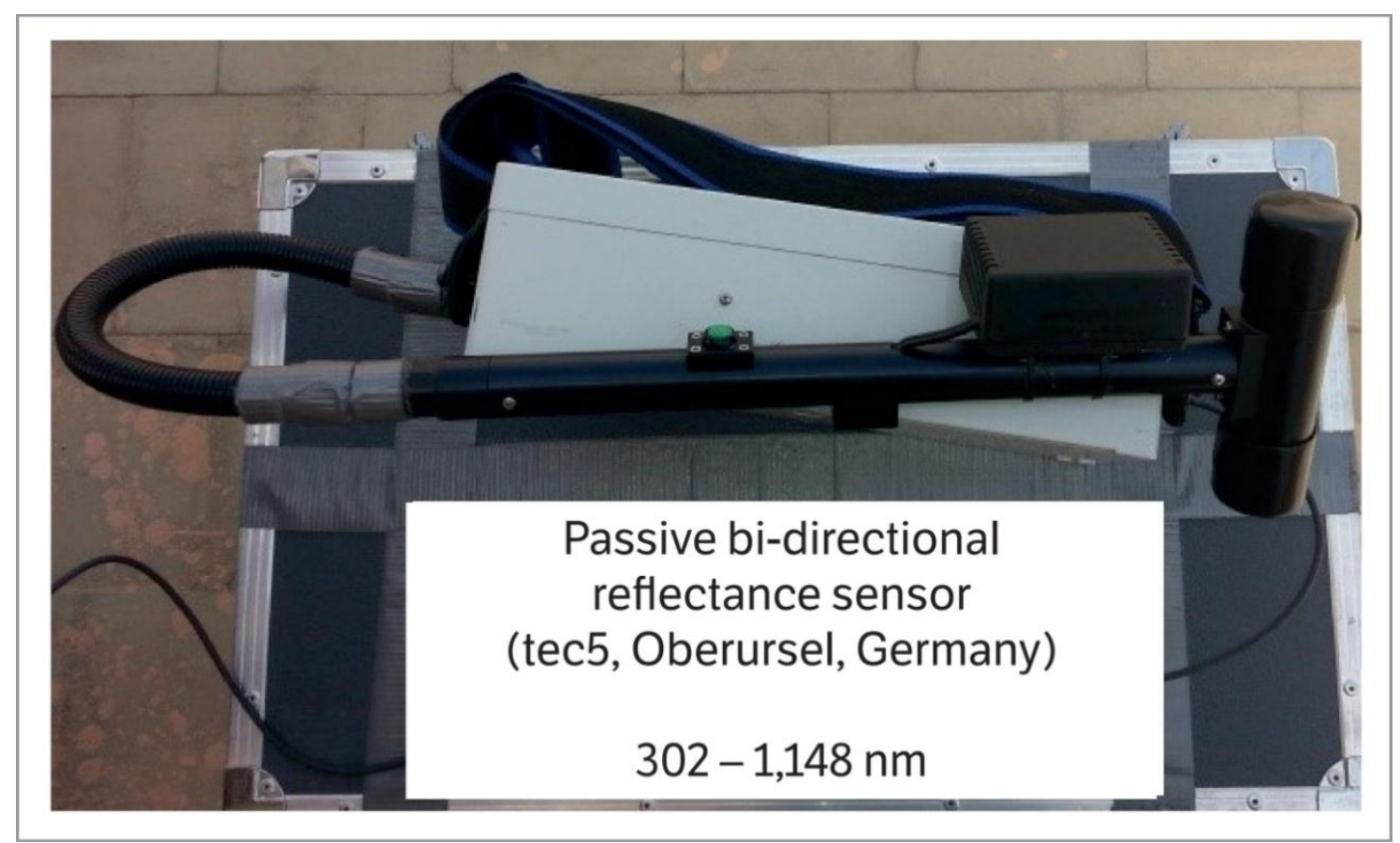

Figure 2. The Field Spectral radiometer Hand-Held instrument

\section{RERSULTS}

\section{- Spectral reflectance curve}

Spectral amount reflected from leaf surface of each wave length band within 302-1148nm range, with a spectral bandwidth of $2 \mathrm{~nm}$ was measured and plotted in curve to show the behavior of different wavelengths reflect from each tree species leaves. Spectral signature curves resulted from measurement of each tree species were distinctly difference.

Spectral curve formed of bottoms and peaks, bottoms refers to absorption region at $320-500 \mathrm{~nm}$ (violet-blue band) and $670 \mathrm{~nm}$ (the red edge), while peaks express the reflectance regions at green (520$580 \mathrm{~nm})$ and red (701-760nm) bands. Spectral curves of Ficus platyphylla, Ficus lyrata and Ficus altissima had greater reflectance at wavelengths of $701 \mathrm{~nm}$ and above (near-infrared (NIR) region) followed by the rest species (Figure 3). Results showed that curves are clearly separated for all species at near-infrared (NIR) region, so this light region can be used successfully for species classification.

\section{-Digital number (DN)}

The average of reflected range of 302-1148 nm spectral wave length for each tree species was calculated and statistically analyzed, which showed highly significant differences among species in digital numbers (DN) obtained from both upper and lower leaf surface of each tree species (Table 2). Ficus platyphylla, Ficus lyrata and Ficus altissima showed the highest values,
41.94, 40.99 and 32.39 respectively, while the lowest values were recorded in Ficus microcarpa Hawai (6.06) and Ficus benghalensis (7.95) (Figure 4).

\section{Vegetation indices:}

Vegetation indices are a mathematical combination of visible, near-infrared and red-edge bands allow us to delineate the vegetation cover and soil according to the reflectance characteristics of green vegetation. So, they consider an important method for monitoring land use and green cover.

\section{Normalized difference Vegetation index (NDVI)}

Vegetation indices are important methods for monitoring land use and green cover. The most used index is normalized difference vegetation index (NDVI) that reflect the level of changes in amount of green biomass, pigment content and concentration and leaf water stress. Analysis of variance in Table (2) showed a highly significant differences among studied species in NDVI values. Generally, most studied species recorded high NDVI value with maximize value 0.80 for Ficus benjamina, whilst Ficus microcarpa Hawai recorded the lowest NDVI value (0.29) as presented and showed at Figure (5). 


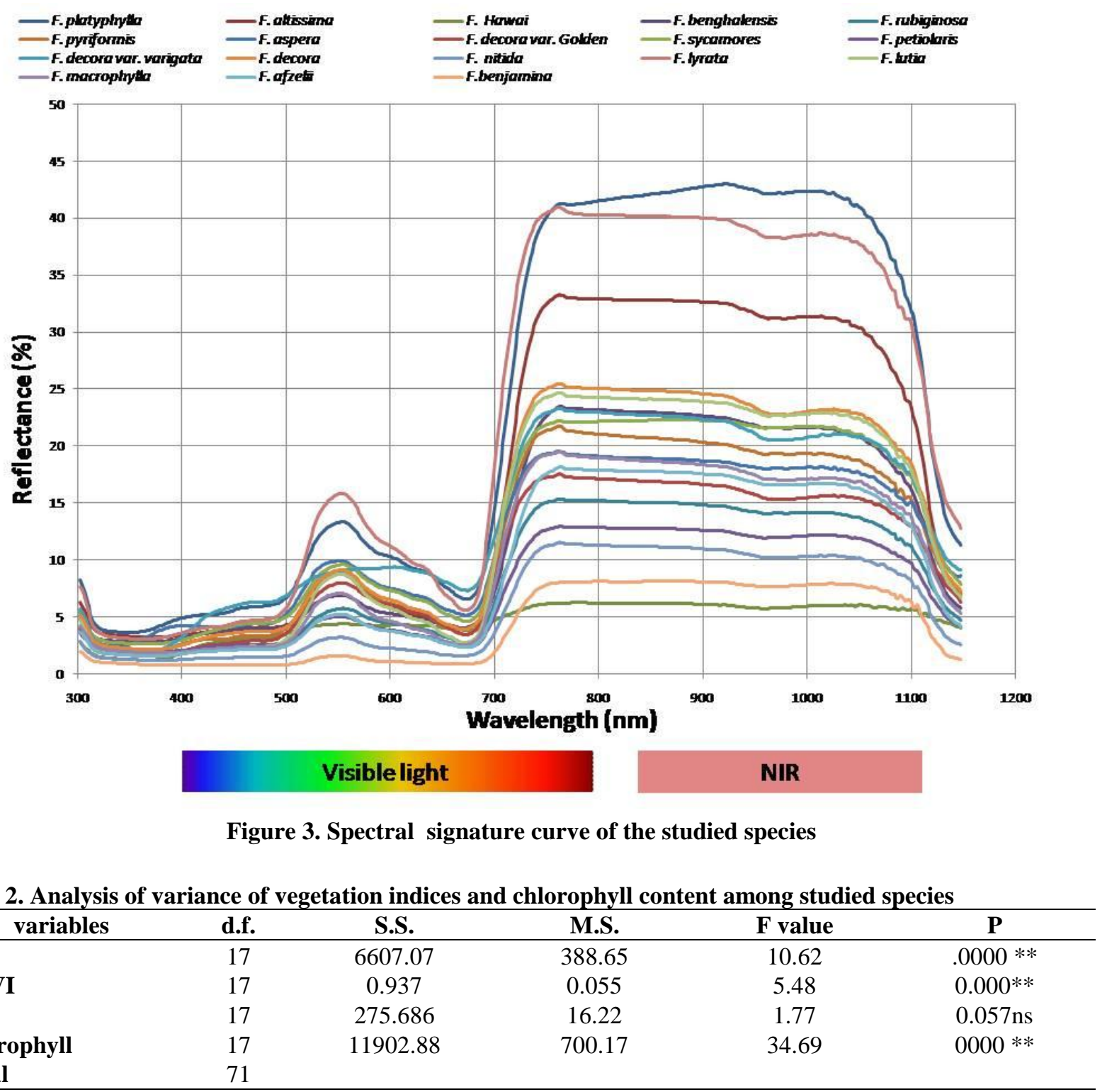

Table 2. Analysis of variance of vegetation indices and chlorophyll content among studied species

\begin{tabular}{lccccc}
\hline \multicolumn{1}{c}{ variables } & d.f. & S.S. & M.S. & F value & P \\
\hline DN & 17 & 6607.07 & 388.65 & 10.62 & $.0000^{* *}$ \\
NDVI & 17 & 0.937 & 0.055 & 5.48 & $0.000^{* *}$ \\
SR & 17 & 275.686 & 16.22 & 1.77 & $0.057 \mathrm{~ns}$ \\
chlorophyll & 17 & 11902.88 & 700.17 & 34.69 & $0000 * *$ \\
Total & 71 & & & & \\
\hline
\end{tabular}

** high significant at 0.01 ns: not significant 


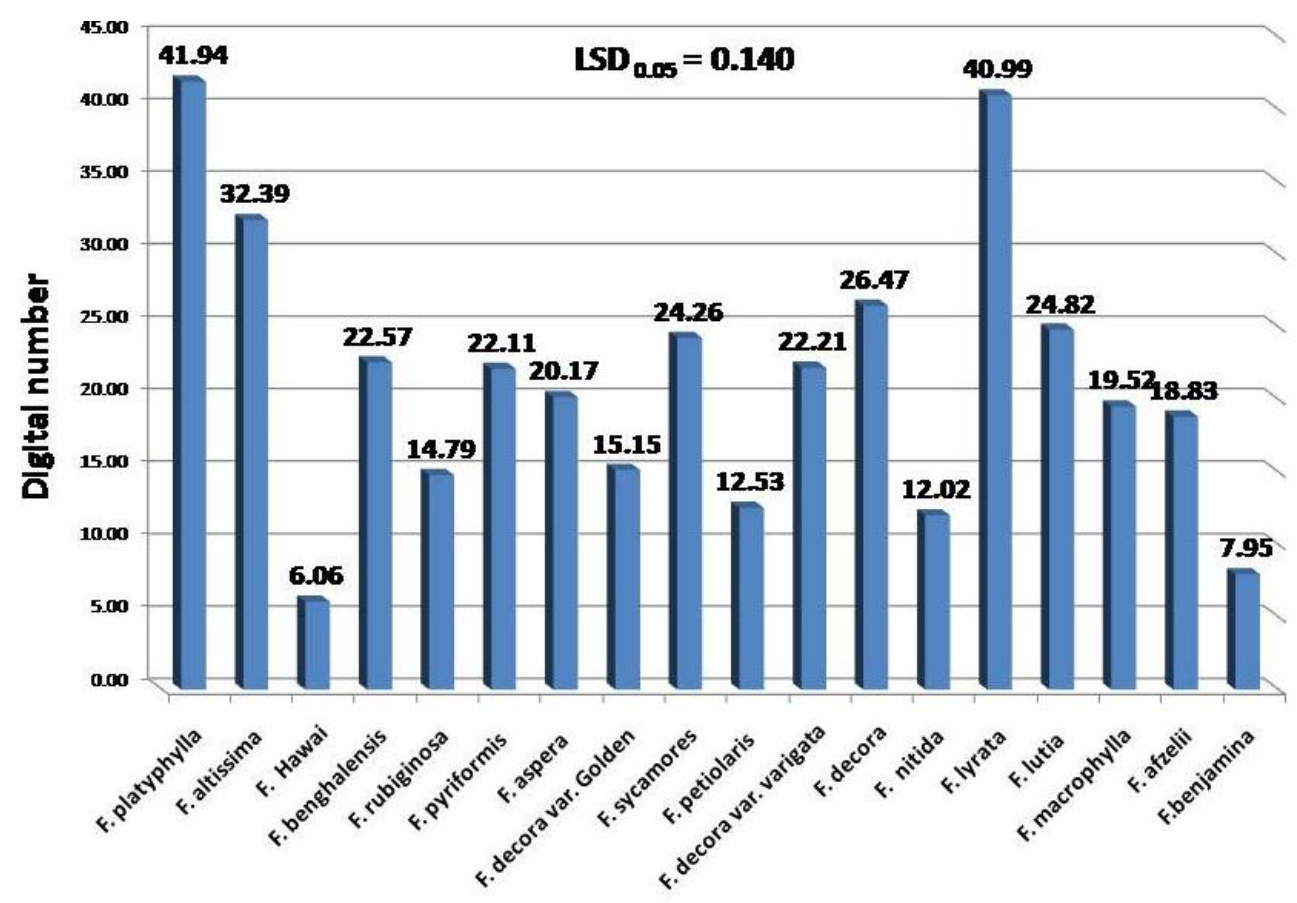

Tree Species

Figure 4. Digital number (DN) of different Ficus species

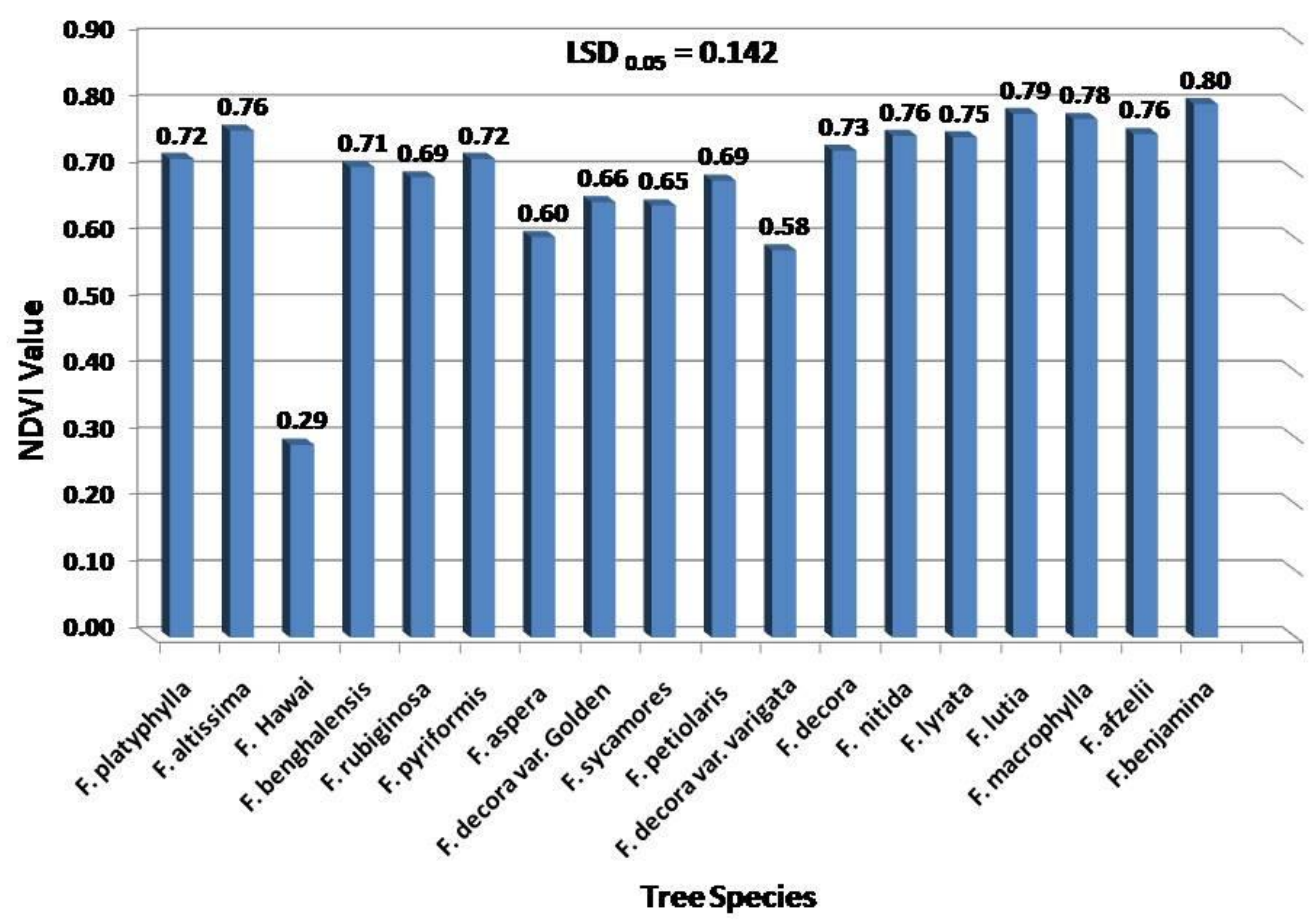

Figure 5. Normalized difference Vegetation index. (NDVI) of studied species 


\section{Simple Ratio (SR)}

Simple ratio or the Ratio Vegetation Index (RATIO) is one of vegetation indices that used to indicate the green cover. Although, statistical analysis of results at Table (2) showed no significant differences among studied species, since the trend of data was the same with the previous indices. For instance, Ficus benjamina, Ficus lyrata, Ficus lutea, and Ficus macrophylla recorded the highest SR values, 9.96, 9.41, 9.12 and 9.01 , respectively, while, the lowest value (2.08) was for Ficus microcarpa Hawai as it presented in Figure (6).

\section{Chlorophyll content}

The amount of total chlorophyll content was measured in leaves, where it's mainly responsible for light absorption and reflection. Analysis of variance presented in Table (2) showed a highly significant difference between species in chlorophyll content. The highest chlorophyll content was detected in leaves of Ficus benghalensis (68.18), followed by that in Ficus microcarpa nitida (64.58), and Ficus platyphylla (61.53). At the same time, Ficus microcarpa Hawai had the lowest chlorophyll content (17.18) as it is cleared in Figure (7).

Correlation between chlorophyll content, NDVI,

\section{DN and RS}

Correlation of Chlorophyll content as an important factor on spectral reflection and absorption of leaves was tested to DN, NDVI and SR indices. Results of correlation analysis showed a highly significant correlation at 0.01 probability between (ChlorophyllNDVI), while (Chlorophyll -SR) was significant at 0.05 probability. On the other hand, the (Chlorophyll -DN) correlation was not significant it illustrated in Table (3).

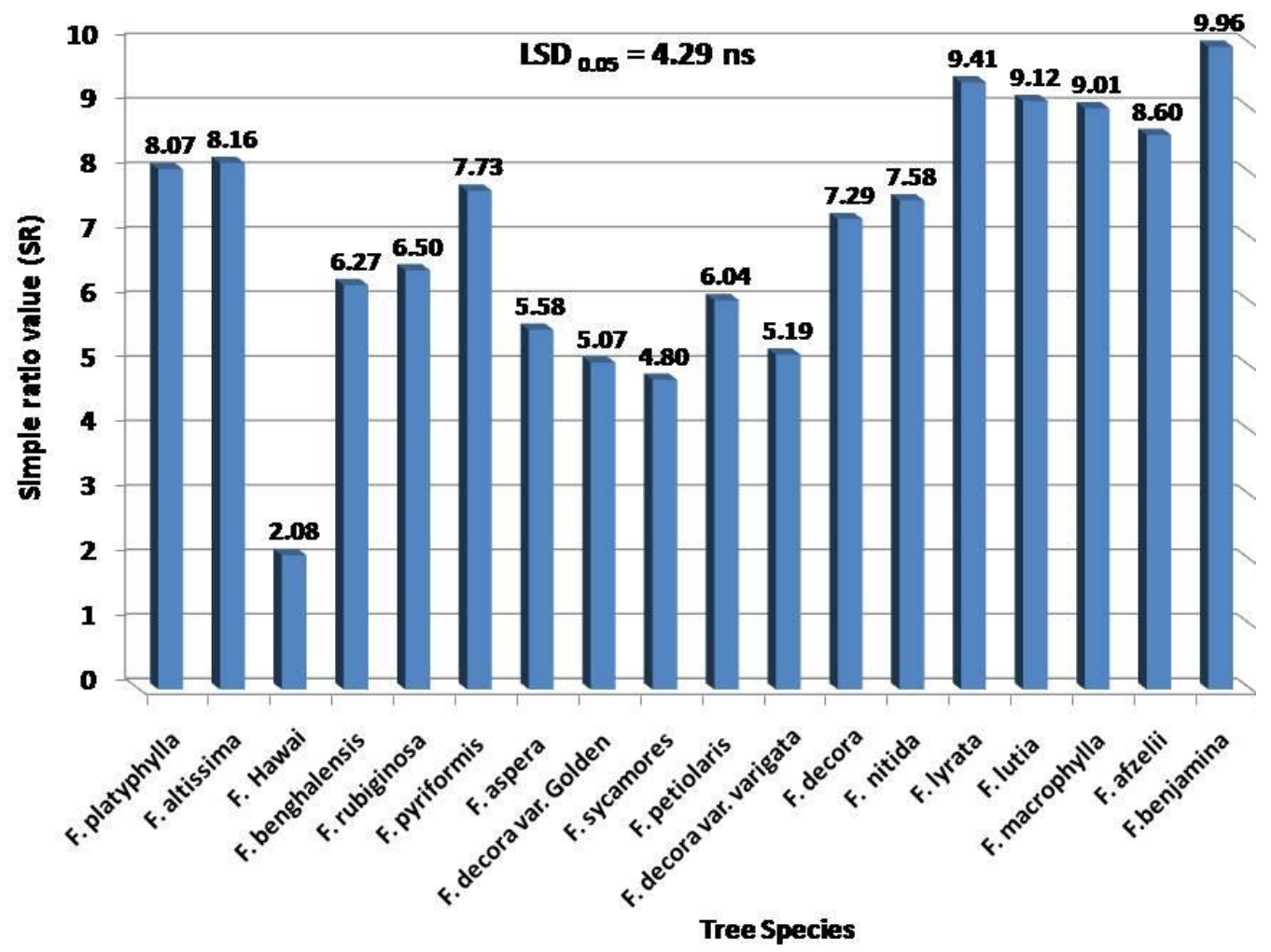

Figure 6. Simple Ratio (SR) of different Ficus species 


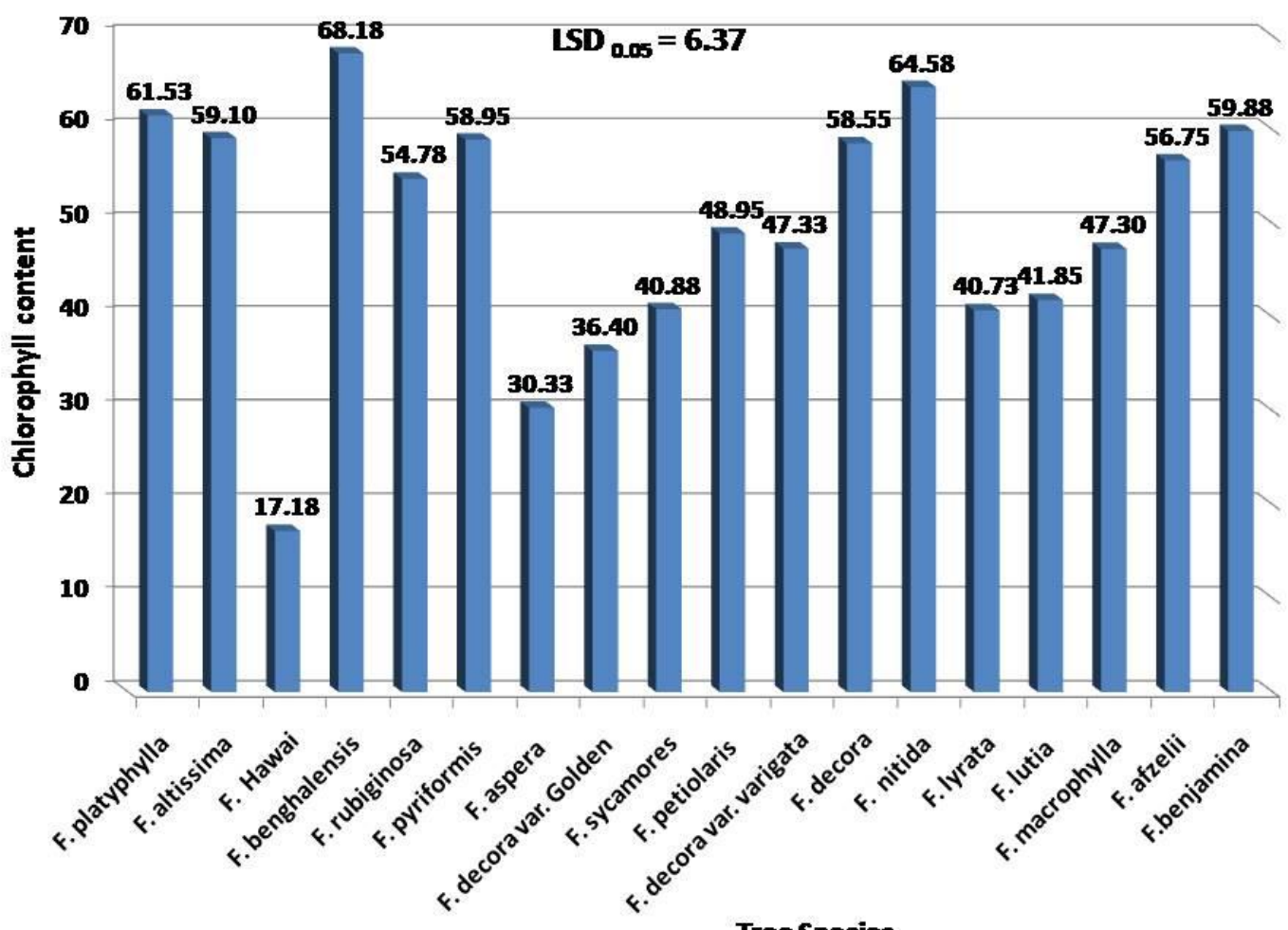

Tree Species

Figure 7. Chlorophyll content of different Ficus species

Table 3. Correlation analysis of Chlorophyll content from one side and NDVI, DN and SR from the other side

\begin{tabular}{lllll}
\hline Variables & $\mathbf{n}$ & Correlation $(\mathbf{r})$ & S.E. & $\mathbf{P}(\mathbf{r}=\mathbf{0})$ \\
\hline Chlorophyll- NDVI & 72 & 0.53 & 0.101 & $0.0000 * *$ \\
Chlorophyll -DN & 72 & 0.16 & 0.118 & $0.1780 \mathrm{~ns}$ \\
Chlorophyll -SR & 72 & 0.29 & 0.115 & $0.0147 *$ \\
\hline ** high significant at 0.01 & ns: not significant & * significant at 0.05 &
\end{tabular}

\section{DISCUSSION}

Spectral curves were different among the studied species according to regions of light absorption and reflection formed in curve bottoms and peaks, respectively. Additionally, the amount of absorption and reflection light according to each leaf species structure and properties. This result was explained by Gates, 1970; Gausman et al., 1977; Williams, 1991; Marek and Sobieraj, 2004 and Baltzer and Thomas, 2005) as generally vegetation has low reflectance and low transmittance in the visible part of the spectrum. This, because of the plant pigments such as, chlorophyll which absorbs violet-blue and red light for storing photosynthetic energy. Green light is not absorbed for photosynthesis and therefore most plants appear green. At the same time, plants reflect radiation highly in the near infrared region because of to the high air cell interface area within leaves. The reflectance of nearinfrared wave band also varies according to the shape and orientation of plant leaves. Therefore, near-infrared reflectance values are often more useful than visible reflectance values in distinguishing forest types.

According to Gregory (1998) the variation of tissue optical properties depending on wavelength. For stance, the lowest variation was in the visible spectral region, while the highest was in near infrared region in green foliage. Furthermore, they reported that the standing litter material, showed minimum variation in the visiblenear infrared region, while the largest differences were occurred in the shortwave- infrared .

It is known that the spectral properties of plant species depend on plant physiology, morphology and anatomy (Kycko et al , 2014 and Jarocinska et al. 2016). 
Species with Large size ,dark color and thick leaves showed a high value of DN, NDVI and chlorophyll content . Also, their spectral curves were highly separated compared to those of other species that being separated, but close to each other. This result was matched with Jacquemoud and Baret, (1990); Apan, et al. (2003) and Uto and Kosugi, 2012) who explained that all vegetation properties containing chlorophyll and other light-absorbing pigments, proteins, water, waxes have a major effect on reflectance of the spectra of vegetation while, Pigments with strong absorption peaks at corresponding narrow spectral bands are estimated by the comparison between absorption peak bands and pigment-independent reference bands. Therefore, vegetation with large quantity of biomass and high chlorophyll concentration showed high value in NDVI, because reflectance at the red band indicates chlorophyll concentration level, where chlorophyll contains narrow peaks at $662 \mathrm{~nm}$ (chlorophyll a) and 642nm (chlorophyll b).

NDVI and SR results were matched to those of Tucker (1979), who mentioned that SR and NDVI were built in the observation that green leaves strongly absorb light in red band by chlorophyll, with maximum absorption at about $690 \mathrm{~nm}$, while the cell walls strongly reflect and transmit light in the NIR region (about 850 $\mathrm{nm}$ ). These results obtained by the NDVI and related visible spectral, which are functional variants of the SR. Also, he found that NDVI was strongly correlated with chlorophyll content and crop characteristics that were directly related to chlorophyll content. Also, Myneni et al. (1995) showed that NDVI was near-linearly related to the chlorophyll content of single soybean leaves and curvilinearly related to the chlorophyll content of soybean canopies (that for surface leaves intercept more light than leaves deeper in the canopy). On the other hand, Quan et al. (2011) mentioned that The ratio vegetation index (RVI) is widely used for green biomass estimations and monitoring, specifically, at high density vegetation coverage, because, this index is very sensitive to vegetation and has a good correlation with plant biomass.

Richmond and Sussman (2003) mentioned that leaf reflectance spectra variability is affect by epidermis thickness, density of prickle hairs on the adaxial leaf surface. Also, the impact of the leaf structure on the reflectance spectra can be significantly altered in the presence of epiphyton at the leaf surface (Brandt and Koch 2003; Klancnik et al., 2015).

Distinctly, vegetation in the NIR region has a high reflectance, with a very rapid transition to low levels between red and NIR regions at $750 \mathrm{~nm}$. This unique character of the vegetation spectrum achieved the possibility to separate vegetation from background material with remotely sensed multispectral data that at least includes NIR and red region reflectance. In general, plant reflectance in Red band depends on chlorophyll content, and reflectance in near infrared one depending on internal structure of the plant cell. Reflectance in these spectra are uncorrelated with each other and they show high spectral contrast for vegetation (Marek and Sobieraj , 2004).

\section{CONCLUSION}

In this research some of Ficus species vary in their leaf shapes, thickness, textures and colors were selected to examine how much spectral waves properties and vegetation indices can differ among such species. Inasmuch as, remote sensing is an important and useful tool to use in plant classification according to differences in tree species leaves shape, chlorophyll content and structure that translated into different amount of spectral reflectance. Distinctly, Ficus species with large, thick and dark green color leaves had the highest value of DN, NDVI, Chlorophyll content and a highly separated spectral curve such as Ficus platyphylla , Ficus lyrata and Ficus altissima, in opposite to species that have small leaves or have light green color like Ficus microcarpa Hawai which recorded the lowest value of all measured indices and formed a low spectral curve. Vegetation in red and NIR spectral Region has high reflectance characteristics that achieve the possibility to separate vegetation types and species. Even small changes in reflectance can be measured, recorded and assigned to a specific species according to leaf spectral properties on three visible bands (near infrared, visible red and visible green) that used in feature extraction. Noticeable that chlorophyll content as a mainly factor of light absorption and reflectance had a high correlation to NDVI and SR indices.

\section{ACKNOWLEDGEMENT}

The authors are gratefully for Miss Therese Labib, (Consultant of Botanic Gardens and gene Bank) for helping in identify and botanically naming Ficus species used in this research.

\section{REFERENCES}

Alanís Flores G.J. 2005. El arbolado urbano en el area metropolitana de Monterrey. Ciencia UANL 8 (1): 20-32.

Apan A., A. Held, A. Phinn, and J.Markley. 2003. Formulation and Assessment of Narrow-Band Vegetation Indices from EO-1 Hyperion Imagery for Discriminating Sugarcane Disease. Proc. Spatial Sci. Conf. 
Avalos G., S. S. Mulkey and K. Kitajma. 1999. Leaf optical properties of trees and lianas in the outer canopy of a tropical dry forest. Biotropica, 31: 517520.

Badr M.D. 2003. Encyclopedia Trees and Environment. Monshaat Al-Maarif - Alexandria, Egypt, pp:747824.

Baltzer J.L. and S.C. Thomas 2005. Leaf optical responses to light and soil nutrient availability in temperate deciduous trees. Am J Bot, 92:241-23.

Baret F., and G. Guyot, 1991. Potentials and limits of vegetation indices for LAI and APAR assessment. Remote Sensing of Environment, 35: 161-173.

Berg C. C. and J. T. Wiebes 1992. African fig trees and fig wasps. Koninklijke Nederlandse Akademie van Wetenschappen. North-Holland, Amsterdam, pp. 1298.

Bhandari A.K. and A. Kumar 2012. Feature extraction using normalized difference vegetation index (NDVI): A Case Study of Jabalpur City, Proceedings of Communication, Computing \& Security. Procedia Technology , 6:. 612-621.

Brandt L.A. and Koch E.W. 2003. Periphyton as a UVB filter on seagrass leaves: a result of different transmittance in the UV-B and PAR ranges. Aquatic Bot, 76:317-27.

Chen J., D. B. McConnell, D. J. Norman and R. J. Henny 2005. The foliage plant industry. Hort. Rev. Amer. Soc. Hort. Sci. 31:47-112.

Clark M. L., D. A. Roberts and D. B. Clark. 2005. Hyperspectral discrimination of tropical rain forest tree species at leaf to crown scales. Remote Sensing of Environment 96: 375-398.

Cochrane M. A. 2000. Using vegetation reflectance variability for species level classification of hyperspectral data. International Journal of Remote Sensing 21: 2075-2087.

Condit I. J. 1969. Ficus: The Exotic Species. Division of Agricultural Science, University of California, Riverside, CA, pp. 265-301.

Dehgan B. 1998. Landscape Plants for Subtropical Climates. University Press of Florida, Gainesville. FL. 638 p.

Elsayed, S., P. Rischbeck and U. Schmidhalter 2015. Comparing the performance of active and passive reflectance sensors to assess the normalized relative canopy temperature and grain yield of drought stressed barley cultivars. Field Crop Research, 177: 148-160.
Fassnacht K. S., S. T. Gower, M. D. MacKenzie, E. V. Nordheim and T. M. Lillesand. 1997. Estimating the leaf area index of north central Wisconsin forests using the Landsat Thematic Mapper, Remote Sens. Environ., 61: 229-245.

Federer W.T. 1955. Experimental Design. MacMillan, NY.

Gates D.M., 1970. Physical and Physiological Properties of Plants, in Remote Sensing: Nat!' Acd. Sci., Washington, D.C., p: 224-252.

Gausman H. W., D. E. Escobar, and E. B. Knipling, 1977. Anomalous leaf reflectance and leaf anatomy of Pe-peromia obtusifolia. PhotogrammetTic Engineering and Re-mote Sensing 43:1183--1185.

Ghadam A. K., G. Nasrollah, H. Farshid and S. Marzieh 2011. Cytotoxic effects of different extracts and latex of Ficus carica L. on HeLa cell line. Ir. J. Pharma. Res., 10:273-277.

Gregory P. A. 1998. Biophysical and Biochemical Sources of Variability in Canopy Reflectance. Remote Sensing of Environment, 64: (3) : 234-253.

Heneidy S.Z. 2010. Plant Atlas of the Botanic Garden Faculty of Science, Alexandria University. Monshaat Al-Maarif - Alexandria, Egypt, pp.429443.

Jacquemoud S. and F. Baret, 1990. PROSPECT: a model of leaf optical properties spectra. Remote Sens. Environ. 34:75-91.

Jarocinska A.M., M. Kacprzyk, A. MarcinkowskaOchtyra, A. Ochtyra, B. Zagajewski and K. Meuleman 2016. The application of APEX images in the assessment of the state of non-forest vegetation in the Karkonosze Mountains. Misc. Geogr. 20: 2127.

Jean-Baptiste F., C. Francois, G. Asner, A. Gitelson, R. Martin, L. Bidel, S. Ustin, G. Lemaire and S. Jacquemoud 2008. Prospect-4 and 5: Advances in the leaf optical properties model separating photosynthetic pigments, Remote Sensing of Environment.112-6:3030-3043.

Klancnik K, D. Gradinjan, A. Gaberscik 2015. Epiphyton alters the quantity and quality of radiation captured by leaves in submerged macrophytes. Aquat Bot 120:229-35.

Kycko M., B. Zagajewski and A. Kozlowska 2014. Variability in spectral characteristics of trampled high-mountain grasslands. Misc. Geogr. 18:10-14.

Lee D. W., R. A. Bone, S. L. Tarsis and D. Storch. 1990. Correlates of leaf optical-properties in tropical forest sun and extreme-shade plants.American Journal of Botany. 77: 370-380. 
Marek M. and A. Sobieraj. 2004. Comparison of several vegetation indices calculated on the basis of a seasonal spotxs time series, and their suitability for land cover and agricultural crop identification. Techn. Sc. No 7. Y.

Martelli A. and J. Barbosa 2010. Analysis of the incidence of tree suppression and its main causes in the urban perimeter of the town of Itapira-SP. REVSBAU 5 (4): 96-109.

Myneni R.B., F. G. Hall, P. J. Seller and A. L. Marshak. 1995. The interpretation of spectral vegetation indexes. IEEE Transactions on Geoscience and Remote Sensing 33: 481- 486.

Nageswara P.P.R., S.V. Shobha, K.S. Ramesh and R.K. Somashekhar. 2005. Satellite -based assessment of Agricultural drought in Karnataka State, Journal of the Indian society of remote sensing . 33 (3). Pp: 429-434.

Padilla F. L. M., M. P. González-Dugo, P .Gavilán and J. Domínguez. 2011. Integration of vegetation indices into a water balance model to estimate evapotranspiration of wheat and corn. Hydrology and Earth System Sciences.15: 1213-1225 http://dx.doi.org/10.5194/hess-15-1213-2011

Quan Z., Z. Xianfeng and J. Miao. 2011. "Ecoenvironment variable estimation from remote sensed data and eco-environment assessment: models and system," Acta Botanica Sinica. vol. 47,pp: 10731080.

Richmond K.E. and M. Sussman. 2003. Got silicon? The non-essentialbeneficial plant nutrient. Curr Opin Plant Biol 6:268-72.

Snedecor G.W. and W.G. Cochran. 1989. Statistical Methods. Sixth Edition. Iowa State University Press. Ames. Iowa. USA. PP: 245-250.
Starr F., K. Starr, and L.L. Loope. 2003. Ficus benjamina. United States Geological SurveyBiological Resources Division. Haleakala Field Station. Maui. Hawaii.

Susan B., B. Rayegani, M. Saati , A. Sharifi , and M. Nasri. 2011. Comparison the accuracies of different spectral indices for estimation of vegetation cover fraction in sparse vegetated areas, The Egyptian Journal of Remote Sensing and Space Sciences 14 :49-56.

Thenkabail P.S., R.B . Smith , E. De Pauw. 2000. Hyperspectral vegetation indices and their relationships with agricultural crop characteristics. Remote Sens. Environ. 71:158-182.

Toscan M.A.G., H.C. Rickli, D. Bartinick, D. Dos Santos, and D. Rossa. 2010. Inventory and analysis of the urban street trees of Vila Yolanda, Foz do Iguazu - State of Parana (Brazil). REVSBAU 5 (3): 165-184.

Tucker C.J. 1979. Red and photographic infrared linear combinations for monitoring vegetation. Remote Sensing of Environment, 8: 127-150.

Tucker, C. J. and P. J. Sellers. 1986. Satellite remote sensing of primary production. International Journal of Remote Sensing, 7: 1395-1416.

Uto K. and Y. Kosugi. 2012. Hyperspectral manipulation for the water stress evaluation of plants ,Contemporary Materials, III (1) Pp: $18-25$.

Vargas-Garzón B.P. and L.F. Molina-Prieto. 2010. Five urban trees causing severe damage to cities. Revista Nodo 5 (9): 115-126.

Williams D.L., 1991. A comparison of spectral reflectance properties at the needle, branch, and canopy level for selected conifer species. Remote Sens. Environ. 35:79-93.

Yadava U. 1986. A rapid and nondestructive method to determine chlorophyll in intact leaves. Hort. Sci., 21(6): 1449-1450. 


\section{الملخص العربي}

\section{التعريف والتفريق الأستشعارى لأنواع الفيكس الموجودة فى مدينة الإسكندرية بأستخدام قياسات الأنعكاس الطيفى \\ نشوى حسن محمد، نادر أحمد الثنهورى و صلاح السيد إمام}

دليل الاختلاف الخضرى الطبيعى (NDVI) وكذلك المحتوى الكلوروفيلى للاوراق نفس الاتجاه فى النتائج من ناحية

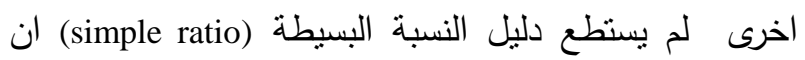
يفرق بشكل معنوى بين الانواع النباتية تحت الدراسة. جدير بالذكر ان منطقة الاشعة تحت الحمراء القريبة هى المنطقة الامثل من الانعكاس الطيفى والتى تظهر الاختلافات بين اوراق انواع النباتات المختلفة حسب صفاتها الظاهرية والتشريحية. من ناحية اخرى اظهرت نتائج التحليل الاحصائى ارتباط معنوى كبير بين محتوى الاوراق من

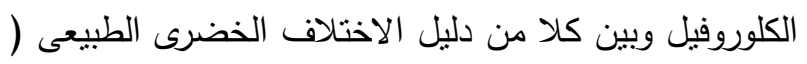
(NDVI ودليل النسبة البسيطة (simple ratio)، بينما لم يكن هناك ارتباط بين المحتوى الكلوروفيللى للاوراق وبين متوسط

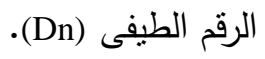

تلك التجربة تمت فى مدينة الاسكندرية على ^/ نوع من الفيكس ( العائلة التينية) لاختبار كيف يمكن للاستشعار عن مدئه الانه بعد كاداة تكنولوجية تطبيقية وكذلك الدلائل الخضرية ان تفرق بين نوع الغطاء النباتى الموجود وهذا بناء على اختلاف وداء الخواص الطيفية لاوراق كل نوع نباتى. اظهرت النتائج اختلاف معنوى فى خواص الامتصاص والانعكاس الطيفى لكل نوع نباتى وكان هذا الاختلاف واضح فى اختلاف المنحنيات الطيفية (spectral curve) لكل نوع نباتى وكذلك

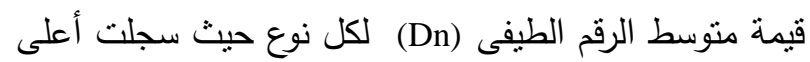
القيم للانواع الفيكس بلاتيفيلا، الفيكس ليراتا و الفيكس التيسيما وهى انواع ذات اوراق كبيرة الحجم ، سميكة ، لها لهات لون اخضر داكن ، على عكس الفيكس هاواى ذو الاوراق صغيرة الحجم ولون اخضر مبرقش مع الابيض والذى سجل اقل متوسط للرقم الطيفى والمنحنى الطيفى ـ هذا وقد سجل 